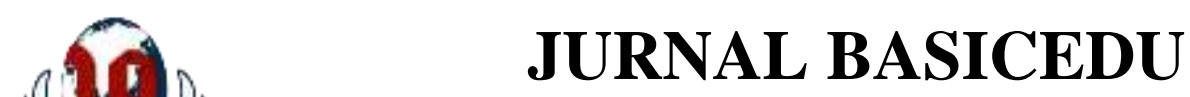

Volume 5 Nomor 6 Tahun 2021 Halaman 6385 - 6400

Research \& Learning in Elementary Education

https://jbasic.org/index.php/basicedu

\title{
Pengembangan Pembelajaran Matematika Berbasis Pendekatan Pembelajaran Mengalami Interaksi Komunikasi dan Refleksi (MIKIR)
}

\author{
Indra Maryanti $^{1 凶}$, Nur 'Afifah ${ }^{2}$, Ismail Saleh Nasution ${ }^{3}$, Sri Wahyuni ${ }^{4}$ \\ Pendidikan Matematika ,Universitas Muhammadiyah Sumatera Utara, Indonesia ${ }^{1,2,3,4}$ \\ E-mail: indramaryanti@umsu.ac.id ${ }^{1}$, nurafifah@umsu.ac.id ${ }^{2}$, ismailsaleh@umsu.ac.id ${ }^{3}$, \\ Sri.wayu90@gmail.com ${ }^{4}$
}

\begin{abstract}
Abstrak
Penelitian ini akan mengamati bagaimana Pengembangan Pembelajaran Matematika Berbasis Pendekatan Pembelajaran Mengalami Interaksi Komunikasi dan Refleksi (MIKIR) di Jurusan Pendidikan Matematika UMSU. Penelitian ini merupakan penelitian kualitatif dengan jenis penelitian studi kasus. Subjek penelitian ini adalah dosen dan mahasiswa. Pengumpulan data diambil melalui wawancara, observasi, dokumentasi dan catatan lapangan. MIKIR merupakan suatu pendekatan pembelajaran yang dicetuskan oleh Tanoto Foundation pada Tahun 2018 silam. MIKIR merupakan singkatan dari Mengalami, Interaksi, Komunikasi, dan Refleksi. Hasil dari penelitian ini menjelaskan bahwa dalam proses pengembangan pembelajaran matematika dengan pendekatan pembelajaran MIKIR terdapat beberapa komponen pendukung agar proses pembelajaran bisa maksimal dan berjalan sesuai dengan tujuan dari suatu pembelajaran, yaitu perencanaan pembelajaran, pelaksanaan pembelajaran, evaluasi pembelajaran, peran dosen dalam proses pembelajaran, serta peran kampus dalam pengembangan pembelajaran matematika dengan pendekatan pembelajaran mikir. Setiap pembelajaran dengan menggunakan pendekatan pembelajaran MIKIR dosen selalu berusaha untuk kreatif dan inovatif dalam mempersapkan bahan ajar dan skenario pembelajaran. Pendekatan pembelajaran MIKIR memliki beberapa unsur yang terdapat didalamnya, yaitu: mengalami, interaksi, komunikasi, dan refleksi. Hal tersebut merupakan unsur dari pembelajaran MIKIR yang dalam proses pembelajarannya tidak harus dilaksanakan secara berurutan tetapi harus ada dalam pembelajaran.
\end{abstract}

Kata Kunci: Pembelajaran Matematika, Pendekatan Pembelajaran MIKIR.

\begin{abstract}
This study will observe how the Development of Mathematics Learning Based on the Learning Approach Experiences Communication and Reflection Interaction (MIKIR) in the Mathematics Education Department of UMSU. This research is qualitative research with the type of case study research. The subjects of this research are lecturers and students. Data collection was taken through interviews, observations, documentation, and field notes. MIKIR is a learning approach that was initiated by the Tanoto Foundation in 2018. MIKIR stands for Experiencing, Interaction, Communication, and Reflection. The results of this study explain that in the process of developing mathematics learning with the MIKIR learning approach there are several supporting components so that the learning process can be maximized and run by the objectives of a lesson, namely learning planning, learning implementation, learning evaluation, the role of lecturers in the learning process, and the role of the campus in the development of mathematics learning with a thinking learning approach. Every lesson using the MIKIR learning approach, the lecturer always tries to be creative and innovative in preparing teaching materials and learning scenarios. The MIKIR learning approach has several elements contained in it, namely: experiencing, interaction, communication, and reflection. This is an element of MIKIR learning which in the learning process does not have to be carried out sequentially but must be present in learning.
\end{abstract}

Keywords: Mathematics Learning, MIKIR Learning Approach.

Copyright (c) 2021 Indra Maryanti, Nur’Afifah, Ismail Saleh Nasution, Sri Wahyuni

Corresponding author :

Email : indramaryanti@umsu.ac.id

DOI : https://doi.org/10.31004/basicedu.v5i6.1814

ISSN 2580-3735 (Media Cetak)

ISSN 2580-1147 (Media Online) 
6386 Pengembangan Pembelajaran Matematika Berbasis Pendekatan Pembelajaran Mengalami Interaksi Komunikasi dan Refleksi (MIKIR) - Indra Maryanti, Nur 'Afifah, Ismail Saleh Nasution, Sri Wahyuni DOI : https://doi.org/10.31004/basicedu.v5i6.1814

\section{PENDAHULUAN}

Matematika adalah salah satu mata pelajaran yang diajarkan pada pendidikan formal. Pada perdosenan tinggi, matematika pun diajarkan, ada yang secara umum dan khusus. Pengajaran matematika yang dilakukan secara khusus terdapat pada jurusan maupun program studi pendidikan matematika.

Salah satu tujuan pembelajaran matematika pada kurikulum 2013 sebagaimana termuat dalam lampiran Permen No.58 Tahun 2014 bagian Pedoman Mata Pelajaran Matematika adalah memahami konsep matematika yang merupakan kompetensi dalam menjelaskan keterkaitan antarkonsep dan menggunakan konsep maupun algoritma secara luwes, akurat, efisien, dan tepat dalam pemecahan masalah. Adapun salah satu indikator pencapaian kompetensi tersebut adalah menyajikan konsep dalam berbagai macam bentuk representasi matematis berupa tabel, grafik, diagram, gambar, sketsa, model matematika, atau cara lainnya (Depdikbud, 2013, pp. 325-326).

Sejalan dengan hal tersebut, menurut National Council of Teacher Mathematics (NCTM) sebagaimana dikutip oleh Asikin (2011:40) menyatakan bahwa ada lima standar proses pembelajaran matematika yang harus dikuasai peserta didik yaitu (1) Belajar untuk memecahkan masalah (mathematical problem solving); (2) Belajar untuk bernalar dan bukti (mathematical reasoning and proof); (3) Belajar untuk berkomunikasi (mathematical communication); (4) Belajar untuk mengaitkan ide (mathematical connection); dan (5) Belajar untuk mempresentasikan (mathematical presentation). Pada mulanya hanya terdapat 4 standar dalam proses pembelajaran matematika yang direkomendasikan di dalam NCTM yaitu kemampuan pemecahan masalah, kemampuan penalaran, kemampuan komunikasi, dan kemampuan koneksi matematis. Representasi masih dianggap sebagai bagian dari komunikasi matematis. Namun pada kenyataanya, kemampuan representasi matematis juga merupakan suatu hal yang selalu muncul ketika mempelajari matematika pada semua tingkatan pendidikan, sehingga dipandang bahwa representasi merupakan suatu komponen yang layak diperhatikan. Dengan demikian representasi matematis perlu mendapat penekanan dan dimunculkan dalam proses pengajaran matematika kampus.

Menurut Utami and Dewi (2020), pembelajaran matematika bukan hanya merupakan orientasi pada hasil akhirnya, namun lebih menekankan segala kegiatan dalam proses belajarmengajar yang sedang berlangsung. Sehingga mahasiswa pendidikan matematika tidak hanya mampu menyelesaikan soal-soal dalam matematika, tetapi juga harus mampu memberikan penjelasan materi dan interpretasi terhadap apa yang ia pelajari selama kegiatan belajar-mengajar. Maskar, Dewi, and Puspaningtyas (2020) menyatakan bahwa belajar matematika juga merupakan suatu pembentukan pada pola pikir yang dalam pemahaman menjelaskan suatu pengertian yang ada dalam penalaran di suatu hubungan antara pengertian. Mahasiswa juga diharapkan untuk dapat menggunakan materi matematika ke dalam kehidupan sehari-hari, dan juga untuk mempelajari berbagai ilmu pengetahuan baik matematika atau bukan matematika yang penekanannya ada pada penataan nalar dan pembentukan sikap mahasiswa serta ketrampilannya juga ada dalam penerapan materi matematika. Untuk itu dalam mengatasi suatu permasalahan rendahnya kemampuan pemahaman mahasiswa terhadap filsafat dan sejarah matematika, mahasiswa perlu adanya model pembelajaran yang pastinya inovatif serta efektif agar dapat mendorong mahasiswa di dalam kelas meskipun kegiatan tersebut daring. Maskar and Anderha (2019) menyatakan bahwa berkembangnya zaman akan ditandai berdasarkan kemajuan teknologi informasi yang berbasis internet dengan nama Revolusi Industri 4.0. Mustakim (2020) dalam penelitiannya menyatakan bahwa pembelajaran daring matematika akan menjadi lebih efisien apabila dalam penerapannya guru menggunakan media ajar selain buku, yaitu media sosial.

Guru professional adalah guru yang mampu membelajarkan siswa dengan penuh kesungguhan yang ditandai dengan keaktifan siswa mengikuti pelajaran walaupun dengan berbagai keterbatasan sarana dan prasarana yang dimiliki oleh sekolah. Guru professional dapat dilihat juga dari kemampuannya dalam 
6387 Pengembangan Pembelajaran Matematika Berbasis Pendekatan Pembelajaran Mengalami Interaksi Komunikasi dan Refleksi (MIKIR) - Indra Maryanti, Nur 'Afifah, Ismail Saleh Nasution, Sri Wahyuni DOI : https://doi.org/10.31004/basicedu.v5i6.1814

mengembangkan berbagai pendekatan dan metode pembelajaran di kelas sehingga proses pembelajaran menjadi aktif kratif, inovatif, produktif dan menyenangkan (Yantoro, 2020).

Pembelajaran yang aktif ditandai dengan keterlibatan siswa secara optimal sehingga dapat mengembangkan potensi yang milikinya. Hal ini sesuai dengan pendapat dari Ahmadi (2011:30) yang mengatakan : pembelajaran dikatakan akif dapat dilihat dari keterlibatan siswa secara aktif baik secara fisik maupun secara mental dalam hal mengemukakan penalaran (alasan), menkomunikasikan ide/gagasan, mengemukakan bentuk representasi yang tepat dan mengemukakan semua itu untuk memecahkan masalah. Guru hendaknya dapat mendorong siswa untuk melakukan pembelajaran dengan penemuannya sendiri. Pembelajaran dengan penemuan merupakan satu komponen penting dalam pendekatan konstruktivis (Kurniawan et al., 2016).

Peran guru dalam pembelajaran aktif yang memfungsikan dirinya sebagai fasilitator, dapat membantu peserta didik untuk belajar dan memiliki keterampilan-keterampilan yang diperlukan untuk mencapai tujuan pembelajaran. Dengan demikian sebagai fasilitator guru menyediakan fasilitas pedagogis, psikologis, dan akademik bagi pengembangan dan pembangunan kognitif bagi peserta didik maka guru wajib menguasai teori pendidikan dan model pembelajaran serta mampu dalam penguasaan bahan agar pembelajaran aktif dapat berjalan dengan lancar (Raehang, 2014).

Dalam melaksanakan pembelajaran guru juga dituntut untuk menggunakan media pembelajaran yang inovatif, karena Media pembelajaran adalah merupakan faktor yang mendukung keberhasilan proses pembelajaran di sekolah karena dapat membantu proses penyampaian informasi dari guru kepada siswa ataupun sebaliknya ((Ahern et al., 2016; Khairani \& Febrinal, 2016).

Dalam proses pembelajaran aktif, siswa diharapkan mampu memecahkan masalah dengan peran guru sebagai fasilitator dan bantuan media pembelajaran. Menurut Sternberg dan Ben-Zeev (Hasratuddin, 2018) menyatakan bahwa pemecahan masalah adalah suatu proses kognitif yang membuka peluang memecahkan masalah untuk bergerak dari suatu keadaan yang tidak diketahui bagaimana pemecahannya ke suatu keadaan tetapi tidak mengetahui bagaimana cara memecahkannya. Russefendi (Marhamah et al., 2014) menyatakan, "kemampuan pemecahan masalah sangat penting dalam matematika, bukan saja bagi mereka yang kemudian hari akan mendalami atau mempelajari matematika, melainkan juga bagi mereka yang akan menerapkannya dalam bidang studi lain dan dalam kehidupan sehari-hari”. Dapat diketahui bahwa memecahkan masalah merupakan suatu bagian yang penting dalam matematika dan proses untuk mengembangkan kemampuan berpikir matematika siswa. Ketika siswa dihadapkan pada suatu masalah, maka siswa berusaha untuk menemukan solusinya. Siswa belajar menemukan bagaimana memecahkan soal tersebut untuk mendapatkan penyelesaiannya, mencari hubungan, menganalisis pola, menemukan metode mana yang sesuai dan yang tidak sesuai, menguji hasil dan menilaihasil dari pemikiran temannya (Gunawan \& Putra, 2019).

Untuk menjawab tantangan Abad ke-21 yang berbasis ketrampilan 4Cs (Ketrampilan Abad 21) maka perlu dikembangkan pembelajaran inovatif, aktif, dan reflektif. Jadi mahasiswa tidak hanya memiliki keahlian di bidang keilmuwan tetapi juga memiliki sikap yang baik. Sudah seyogyanya perkuliahan di kampus senantiasa menciptakan kelas yang active learning agar mahasiswa dapat lebih aktif, kritis, dan mampu meningkatkan ketrampilan diri agar mampu bersaing di dunia kampus maupun dunia kerja (Pernantah, 2019).

Banyak pendekatan pembelajaran yang dapat digunakan dalam proses belajar mengajar. Untuk memperoleh hasil yang memuaskan memerlukan pendekatan yang tepat untuk menyampaikan suatu pengetahuan atau materi, sehingga hasilnya sesuai dengan yang diharapkan. Salah satu pendekatan pembelajaran yang tergolong baru yaitu MIKIR, mikir merupakan istilah baru dalam dunia pendidikan yang merupakan singkatan dari "Mengalami Interaksi Komunikasi dan Refleksi" yang di pelopori oleh Tanoto Foundation bekerjasama dengan pemerintah meluncurkan program pembelajaran MIKIR.

Berdasarkan berita yang dirilis 25 Februari 2019 oleh SUMUT POS yang berjudul "Pelatihan Pembelajaran Aktif dan Manajemen Berbasis Kampus dari Tanoto Foundation, Acuan Dosen Mengajar di 
6388 Pengembangan Pembelajaran Matematika Berbasis Pendekatan Pembelajaran Mengalami Interaksi Komunikasi dan Refleksi (MIKIR) - Indra Maryanti, Nur 'Afifah, Ismail Saleh Nasution, Sri Wahyuni DOI : https://doi.org/10.31004/basicedu.v5i6.1814

Kampus" Kordinator Nasional Lembaga Pendidikan Tenaga Kedosenan (LPTK) Mitra, Ajar Budi Kuncoro mengatakan, Tanoto Foundation memiliki program untuk mengintegrasikan antara LPTK dengan kampus. Pelatihan hari ini adalah latihan dosen berkaitan dengan pembelajaran aktif, dosen mempunyai dua tugas utama yakni mempersiapkan calon dosen dan mendampingi para dosen yang ada di kampus. Dengan pelatihan ini, dosen diharapkan bisa mengajarkannya kepada calon dosen (mahasiswa) di kampus sehingga nantinya calon dosen bisa mengajar secara profesional. Salah satu LPTK yang menjadi rekanan TANOTO adalah UMSU (Siregar, 2019).

Penelitian yang mengacu pada pendekatan pembelajaran MIKIR yang dilakukan selama ini masih banyak di level Sekolah Dasar atau Sekolah Menengah Pertama, karena penerapan pendekatan MIKIR ini lebih mudah jika dilakukan pada level pendidikan di tingkat tersebut. Hal ini juga didukung dengan lebih banyaknya guru yang mendapatkan pelatihan dari Tanoto Foundation dibandingkan para dosen dari LPTK. Oleh sebab itu peneliti merasa tertarik untuk melakukan penelitian tentang pendekatan MIKIR ini pada tingkan Perguruan Tinggi.

Penelitian ini mengkolaborasikan antara aplikasi geogebra dengan pendekatan pembelajaran MIKIR pada mata kuliah aplikasi komputer, peneliti berharap dengan menggabungkan aplikasi geogebra sebagai media dan menggunakan pendekatan MIKIR akan diperoleh hasil sesuai yang diharapkan dan menjadi penemuan yang baru dalam dalam pembelajaran di perguruan tinggi. Selanjutnya bagi dosen yang lain agar dapat melakukan penelitian tentang pendekatan MIKIR ini dan mengembangkannya dengan media, motode pembelajaran yang lainnya dan pada materi yang lain lagi.

Hasil penelitian ini diharapkan menjadi temuan baru yang dapat memotivasi para dosen agar selalu dapat melakukan inovasi-inovasi baru dalam melakukan pembelajaran di kelasnya, sehingga akan menjadi contoh bagi mahasiswanya yang juga calon pendidik, sehingga mahasiswa tersebut mempunyai pengalaman belajar yang dapat dia kembangkan nantinya ketika mereka sudah menjadi seorang pendidik. Oleh karena itu penulis tertarik untuk meneliti tentang "Pengembangan Pembelajaran Matematika Berbasis Pendekatan Pembelajaran Mengalami Interaksi Komunikasi dan Refleksi (MIKIR)".

\section{METODE}

Peneliti memilih model penelitian kualitatif dengan jenis studi kasus karena peneliti ingin mengetahui secara rinci bagaimana pengembangan pembelajaran matematika berbasis pendekatan pembelajaran mengalami interaksi komunikasi dan refleksi (MIKIR) di jurusan Pendidikan Matematika UMSU. Dalam proses penelitian kualitatif studi kasus peneliti tidak memerlukan waktu yang relatif lebih lama dari penelitian pada umumnya. Dan dalam penelitian jenis ini peneliti dapat menyajikan data dan temuan yang sangat berguna, memberikan informasi penting, dan memberikan kesempatan untuk memperoleh wawasan.

Instrumen penelitian yang digunakan adalah data yang diperoleh dari sumber data:

1. Sumber data primer

Sumber data primer atau utama yaitu sumber data yang diambil peneliti baik berupa kata-kata dan aktivitas atau tindakan. Sumber data primer diperoleh dari ketua prodi, dosen, karyawan, dan mahasiswa di jurusan pendidikan matematika UMSU. Adapun data primer yang dibutuhkan yaitu pengembangan pembelajaran matematika berbasis pendekatan pembelajaran mengalami interaksi komunikasi dan refleksi (MIKIR) di jurusan pendidikan matematika UMSU.

2. Sumber data sekunder

Sumber data sekunder atau tambahan yaitu sumber data yang tidak langsung memberikan data kepada peneliti. Sumber data sekunder ini berfungsi sebagai pendukung dan melengkapi sumber data primer. Sumber data sekunder dapat berupa buku referensi dan dokumen. Sumber data sekunder untuk menggali informasi mengenai pendekatan pembelajaran mikir dan pengembanagn pembelajaran matematika adalah dengan 
dokumen atau sumber lainnya yang berkaitan dengan kebutuhan penelitian, seperti artikel, jurnal, serta bukubuku yang berkaitan dengan pendekatan pembelajaran MIKIR.

\section{Metode Observasi}

Dalam penelitian ini, peneliti megguunakan teknik observasi tak berstruktur dan teknik observasi berstruktur. Teknik observasi ini dilakukan untuk mencari data-data yang berkaitan dengan pelaksanaan pembelajaran dengan pendekatan pembelajaran mikir yaitu, persiapan yang dilakukan dosen sebelum pembelajaran, aktifitas dosen selama proses pembelajaran berlangsung. Dan yang akan diobservasi guna mendapatkan informasi dalam penelitian ini adalah dosen dan mahasiswa jurusan pendidikan matematika UMSU.

Dalam pengumpulan data digunakan alat bantu berupa pedoman observasi yang berkaitan dengan fokus penelitian. Adapun pedoman observasi tentang pelaksanaan pembelajaran dengan pendekatan pembelajaran mikir pada mahasiswa jurusan pendidikan matematika.

\section{Metode Wawancara}

Sumber data dalam teknik wawancara ini adalah ketua prodi, dosen dan mahasiswa jururan pendidikan matematika UMSU.

Dalam penelitian kualitatif ini, peneliti menggunakan teknik analisis data deskriptif dalam mengnalisis data hasil penelitianya yang meliputi proses mencari dan menyusun secara sistematis data yang diperoleh dari observasi, wawancara, dokumentasi dan catatan lapangan.

Analisis data pada penelitian kualitatif dilakukan melalui pengaturan data secara logis dan sistematis. Analisis data itu dilakukan sejak awal peneliti terjun ke lokasi penelitian hingga kahir penelitian (pengumpulan data). Penelitian kualitatif menggunakan analisis induktif yang berarti bahwa kategori-kategori, tema-tema, dan pola berasal dari data. Kategori-kategori yang muncul dari hasil catatan lokasi peneliti, berasal dari dokumen dan hasil wawancara tidak ditentukan sebelum pengumpulan data (Ghony \& Almansur, 2017). Penelitian ini akan dianalisis secara kualitatif untuk mengolah data dari lapangan yaitu:

\section{Pengumpulan data}

Proses pengumpulan data dimulai dari menelaah seluruh data yang diperoleh dengan menggunakan beberapa teknik yaitu observasi, wawancara mendalam (indepth interview), dan dokumentasi yang diperoleh dari penelitian.

2. Reduksi data

Data yang diperoleh dari lapangan jumlahnya cukup banyak, untuk itu maka perlu dicatat secara teliti dan rinci. Seperti telah dikemukakan, semakin lama peneliti ke lapangan, maka jumlah data yang akan semakin banyak, kompleks dan rumit. Untuk itu perlu segera dilakukan analisis data melalui reduksi data. Mereduksi data berarti merangkum memilih hal-hal yang pokok, memfokuskan pada hal-hal yang penting, dicari tema dan polanya. Dengan demikian data yang telah direduksi akan memberikan gambaran yang lebih jelas, dan mempermudah peneliti untuk melakukan pengumpulan data selanjutnya, dan mencarinya bila diperlukan (Sugiyono, 2016).

\section{Penyajian data}

Setelah data direduksi, maka langkah selanjutnya adalah penyajian data atau mendisplay data. Dalam penelitian kualitatif, penyajian data bias dilakukan dalam bentuk uraian singkat, bagan, hubungan antar kategori, flowchart dan sejenisnya. Dengan penyajian data, maka akan memudahkan untuk memahami apa yang terjadi, merencanakan kerja selanjutnya berdasarkan apa yang dipahami. Selain teks yang naratif, juga dapat berupa grafik, matrik, network (jejaring kerja) dan chart (Sugiyono, 2016). 
4. Kesimpulan dan verifikasi

Langkah keempat dalam menganalisis data kualitatif adalah menarik kesimpulan dan verfikasi. Kesimpulan dalam penelitian kualitatif merupakan temuan baru yang sebelumnya belum pernah ada. Temuan dapat berupa deskripsi atau gambaran suatu obyek yang sebelumnya masih remang-remang atau gelap sehingga setelah diteliti menajadi jelas, dapat berupa hubungan kausal atau interaktif, hipotesis atau teori, (Sugiyono, 2016).

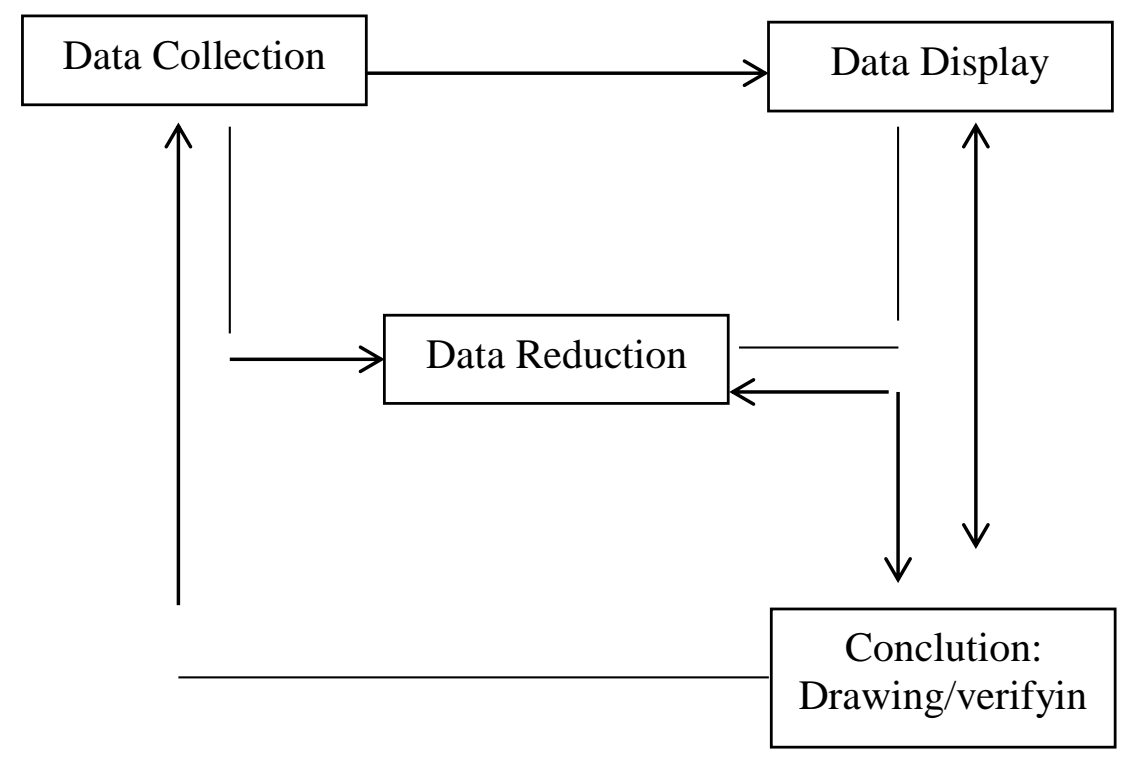

Gambar 1. Analisis data Model Interaktif

Komponen dalam analisis data (Interactive Model)

\section{HASIL DAN PEMBAHASAN}

Data penelitian diperoleh dengan menggunakan metode wawancara, observasi, dokumentasi, serta catatan lapnangan. Kemudian hasil penelitian dianalisis oleh peneliti dengan menggunakan teknik deskriptif kualitatif, yang artinya peneliti akan menggambarkan, menguraikan, serta menginterpretasikan seluruh data yang terkumpul sehingga mampu menperoleh gambaran secara umum dan menyeluruh.

Berdasarkan hasil penelitian yang dilakukan di pendidikan matematika UMSU mengenai pelaksanaan pembelajaran menggunakan pendekatan pembelajaran mengalami, interaksi, komunikasi, dan refleksi (mikir) adalah sebagai berikut:

a. Perencanaan Pembelajaran dengan menggunakan Pendekatan Mikir

Berdasarkan hasil wawancara yang dilakukan oleh peneliti dengan dosen pengampu mata kuliah pada tanggal 5-11 Juli 2021. Beliau mengungkapkan bahwa beliau sudah memahami pendekatan pembelajaran mengalami, interaksi, komunikasi, dan refleksi (mikir) dan telah menerapkan di kelas. Untuk cara menerapkan pendekatan ini di kelas dosen mempelajari karakteristik siswa dan karakteristik materi yang akan disampaikan kepada mahasiswa.

Dosen pengampu mata kuliah pun sudah mengetahui istilah pendekatan pembelajaran mikir. Oleh sebab itu setiap pembelajarn beliau menggunakan pendekatan pembelajaran mikir di kelas yang beliau ampu. Dalam setiap penyusunan rencana pembelajaran yang bisa disebut skenario pembelajaran, beliau selalu melakukan anlisis materi ajar sebelum menyusun skenario pembelajaran tersebut, khususnya untuk menentukan media yang digunakan dalam materi tersebut selalu menyesuaikan dengan bahan-bahan yang ada dan disesuaikan 
6391 Pengembangan Pembelajaran Matematika Berbasis Pendekatan Pembelajaran Mengalami Interaksi Komunikasi dan Refleksi (MIKIR) - Indra Maryanti, Nur 'Afifah, Ismail Saleh Nasution, Sri Wahyuni DOI : https://doi.org/10.31004/basicedu.v5i6.1814

dengan keadaan mahasiswa sehingga mampu mencapai tujuan dan keberhasilan dalam proses pembelajaran. Berikut adalah skenario yang digunakan oleh dosen pengampu.

\section{SKENARIO PERKULIAHAN}

Mata Kuliah

Topik

Tujuan
: Program Aplikasi Komputer

: Software Geogebra

: 1. Menghitung Panjang dan Besar Sudut Segitiga

2. Menghitung Keliling dan Luas Segitiga

Metode

: Penemuan, tanya jawab, diskusi

\begin{tabular}{|c|c|c|}
\hline Langkah-langkah Pembelajaran & $\begin{array}{l}\text { Pengel. } \\
\text { Kelas)* }\end{array}$ & Waktu \\
\hline \multicolumn{3}{|l|}{ Kegiatan Pendahuluan } \\
\hline $\begin{array}{l}\text { 1. Dosen menyampaikan tujuan perkuliahan Melalui Daring (Zoom) } \\
\text { 2. Dosen mengajak mahasiswa mengingat dan berbagi } \\
\text { pengalaman/pengetahuan tentang } \\
\text { - Panjang sisi dan Besar sudut } \\
\text { - Menghitung Keliling dan Luas Segitiga } \\
\text { 3. Dosen membagi mahasiswa dalam beberapa kelompok (satu kelompok } \\
\text { terdiri dari 3-4 orang) (Breakout room) }\end{array}$ & Klas & 5 \\
\hline \multicolumn{3}{|l|}{ Kegiatan Inti } \\
\hline $\begin{array}{l}\text { 1. Mahasiswa mengamati } 2 \text { gambar segitiga pada LK } \\
\text { 2. Dosen meminta mahasiswa untuk membaca dan memahami informasi } \\
\text { berkaitan dengan panjang sisi dan besar sudut-sudut dalam segitiga } \\
\text { (Informasi pada LK) } \\
\text { 3. Dosen meminta mahasiswa untuk membaca dan memahami informasi } \\
\text { berkaitan dengan Luas dan keliling segitiga (Informasi pada LK) }\end{array}$ & Ind & $\begin{array}{l}5 \\
5\end{array}$ \\
\hline $\begin{array}{l}\text { 4. Mahasiswa berdiskusi: } \\
\text { 1) Panjang sisi-sisi segitiga } \\
\text { 2) Besar Sudut-sudut Segitiga } \\
\text { 3) Langkah-langkah menemukan panjang sisi segitiga } \\
\text { 4) Langkah-langkah menemukan besar sudut segitiga } \\
\text { 5) Langkah-langkah menemukan Keliling segitiga } \\
\text { 6) Langkah-langkah menemukan luas segitiga }\end{array}$ & kel & $45^{\prime}$ \\
\hline 5. Setiap kelompok menjelaskan hasil diskusinya (presentasi) & Kel & \\
\hline $\begin{array}{l}\text { 6. Mahasiswa menyelidiki untuk menemukan langkah-langkah dalam } \\
\text { menemukan panjang dan besar sudut sudut segi-n }\end{array}$ & Kel & \\
\hline $\begin{array}{l}\text { 7. Mahasiswa mempresentasikan hasil kerja kelompok, terutama: } \\
\text { a. Panjang sisi-sisi segitiga } \\
\text { b. Besar Sudut-sudut Segitiga } \\
\text { c. Langkah-langkah menemukan panjang sisi segitiga } \\
\text { d. Langkah-langkah menemukan besar sudut segitiga } \\
\text { e. Langkah-langkah menemukan Keliling segitiga }\end{array}$ & Klas & 10 ' \\
\hline
\end{tabular}


6392 Pengembangan Pembelajaran Matematika Berbasis Pendekatan Pembelajaran Mengalami Interaksi Komunikasi dan Refleksi (MIKIR) - Indra Maryanti, Nur 'Afifah, Ismail Saleh Nasution, Sri Wahyuni DOI : https://doi.org/10.31004/basicedu.v5i6.1814

\begin{tabular}{|l|c|c|}
\hline f. Langkah-langkah menemukan luas segitiga & & \\
\hline Kegiatan Penutup & I & 5 \\
\hline $\begin{array}{l}\text { 1. Dosen meminta mahasiswa untuk melakukan refleksi dengan } \\
\text { pertanyaan: }\end{array}$ & \\
a. Bagaimana menemukan panjang sisi segitiga? & \\
b. Bagaimana menemukan besar sudut sisi segitiga? & \\
c. Bagaimana menemukan Keliling segitiga? & \\
d. Bagaimana menemukan luas segitiga? & \\
e. bagaimana Langkah-langkah dalam menemukan luas dan keliling & \\
f. Apagi- n beraturaturan & & \\
\hline $\begin{array}{l}\text { 2. Dosen memberi penguatan pembelajaran yang telah dilakukan terutama } \\
\text { dalam menentukan besar sudut, panjang sisi, keliling dan luas segitiga } \\
\text { dan segi-n }\end{array}$ & Klas. & 5 \\
\hline *) I = Individual; Ps = Pasangan; Klp.= Kelompok; Klas. = Klasikal & & \\
\hline
\end{tabular}

Berdasarkan hasil pengkajian dokumen skenario pembelajaran dengan pendekatan pembelajaran mikir, dapat dilihat bahwa dosen sudah menyusun skenario pembelajaran sesuai dengan rumusan pembelajaran mikir dan dalam menyusun kegiatan pembelajaran sudah memasukkan unsur-unsur dari pendekatan pembelajaran mikir.

Prosedur pelaksanaan kegiatan pembelajaran dengan pendekatan mikir dibagi dalam beberapa tahapan yaitu mengalami (mengamati,melakukan percobaan, berwawancara, dan membuat sesuatu), interaksi (berdiskusi, bertanya atau mempertanyakan, meminta pendapat, bekerja dalam kelompok, saling menjelaskan hasil kerja, dan menjawab pertanyaan dari dosen), komunikasi (mendemonstrasikan, menjelaskan, bercerita, melaporkan dalam bentuk lisan atau tulisan, mengemukakan pendapat atau pikiran, serta berbicara atau presentasi di depan) dan refleksi (memikirkan kembali hasil kerja atau pikiran sendiri). Untuk menunjang keberhasilan pembelajaran dengan pendekatan mikir dosen harus memilih strategi, metode dan media pada materi yang akan diajarkan. Dosen menggunakan metode yang disesuaikan dengan materi yang akan disampaikan yang ditekankan pada Student Centre atau berpusat pada mahasiswa.

Agar pembelajaran dengan pendekatan mikir mampu mencapai keberhasilan tentu dalam setiap pembelajaran memerlukan aspek penunjang yaitu media pembelajaran. Media pembelajaran yang digunakan dosen disesuaikan dengan topik yang akan disampaikan kepada mahasiswa, biasanya media pembelajaran diambil dari media elektronik, media cetak, dan yang paling sering adalah dengan membuat media pembelajaran sendiri dengan bahan-bahan yang ada agar memudahkan mahasiswa dalam memahami materi yang disampaikan.

Pemilihan sumber belajar yang dapat digunakan untuk mendukung pembelajaran dengan pendekatan mikir harus diseasuaikan dengan topiknya, seperti halnya dengan media, dosen pengampu mengambil sumber belajar dari media cetak, media elektronik, media online, serta lingkungan sekitar kampus.

Berikut ini adalah deskripsi tentang pelaksanaan pembelajaran dengan pendekatan mikir yang dilakukan oleh dosen pengampu mata kuliah:

1) Mengalami

Dosen menyampaikan tujuan perkuliahan melalui daring (Zoom). Dosen mengajak mahasiswa mengingat kembali dan berbagi pengalaman/pengetahuan tentang: panjang sisi dan besar suduit, menghitung keliling dan luas segitiga. Dosen membagi mahasiswa dalam beberapa kelompok (satu kelompok terdiri dari 3-4 orang) (Breakout room). Kemudian mahasiswa mengamati 2 gambar segitiga pada LK dan meminta mahasiswa untuk membaca dan memahami informasi berkaitan dengan panjang 
6393 Pengembangan Pembelajaran Matematika Berbasis Pendekatan Pembelajaran Mengalami Interaksi Komunikasi dan Refleksi (MIKIR) - Indra Maryanti, Nur 'Afifah, Ismail Saleh Nasution, Sri Wahyuni DOI : https://doi.org/10.31004/basicedu.v5i6.1814

sisi dan besar sudut-sudut dalam segitiga (informasi ada pada LK), selanjutnya mahasiswa diminta untuk membaca dan memahami informasi berkaitan dengan luas dan keliling segitiga (informasi ada pada LK).

2) Interaksi

Mahasiswa berdiskusi tentang: panjang sisi-sisi segitiga, besar sudut-sudut segitiga, langkah-langkah menemukan panjang sisi segitiga, langkah-langkah menemukan besar sudut segitiga, langkah-langkah menemukan keliling segitiga, dan langkah-langkah menemukan luas segitiga (breakout room; LK 1). Berikutnya mahasiswa berdiskusi kembali bagaimana langkah-langkah dalam menemukan panjang dan besar sudut segi-n (breakout room; LK 2). Dibawah pengawasan dosen pengampu mata kuliah.

Berikut ini adalah hasil diskusi mahasiswa:
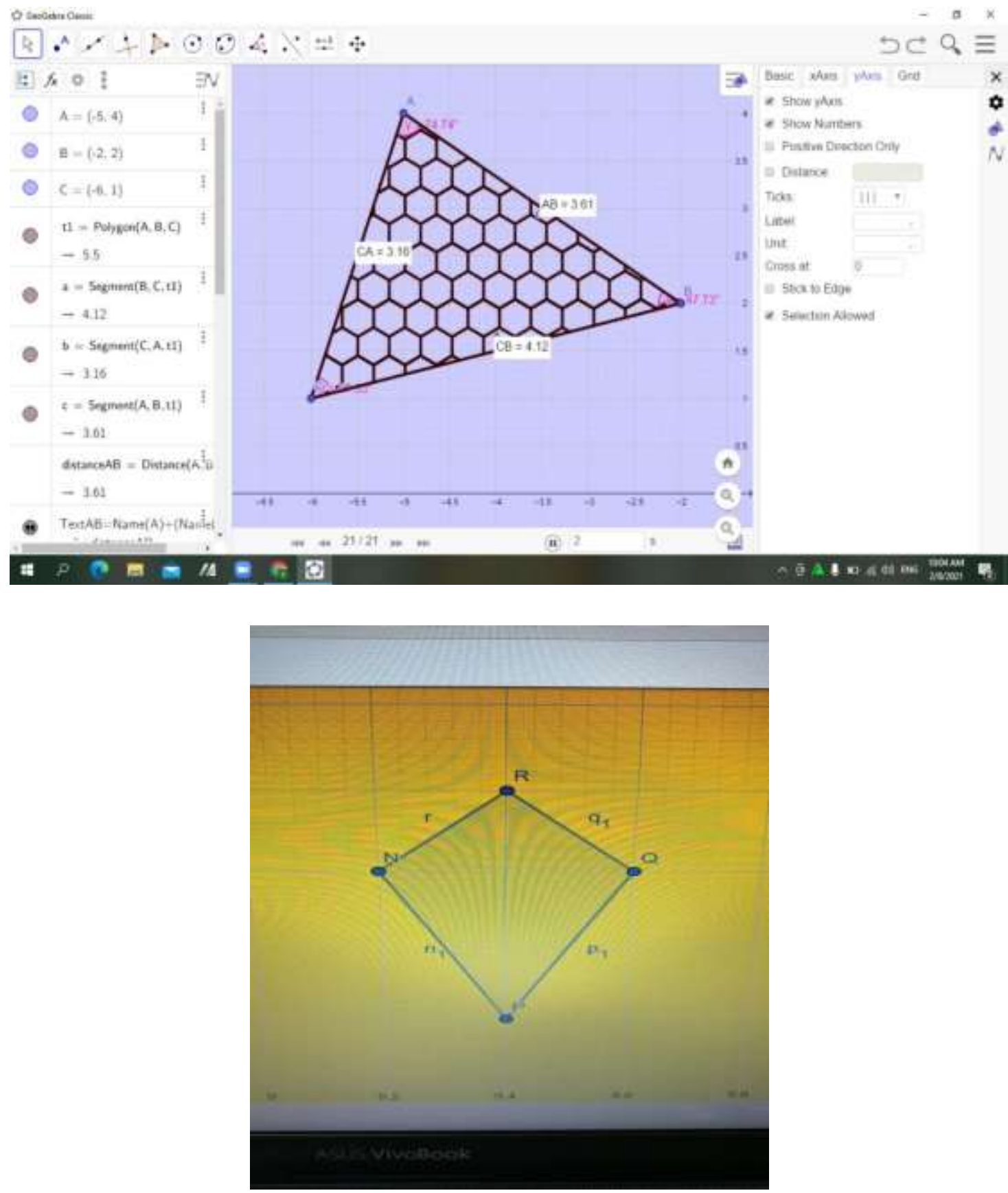
6394 Pengembangan Pembelajaran Matematika Berbasis Pendekatan Pembelajaran Mengalami Interaksi Komunikasi dan Refleksi (MIKIR) - Indra Maryanti, Nur 'Afifah, Ismail Saleh Nasution, Sri Wahyuni DOI : https://doi.org/10.31004/basicedu.v5i6.1814
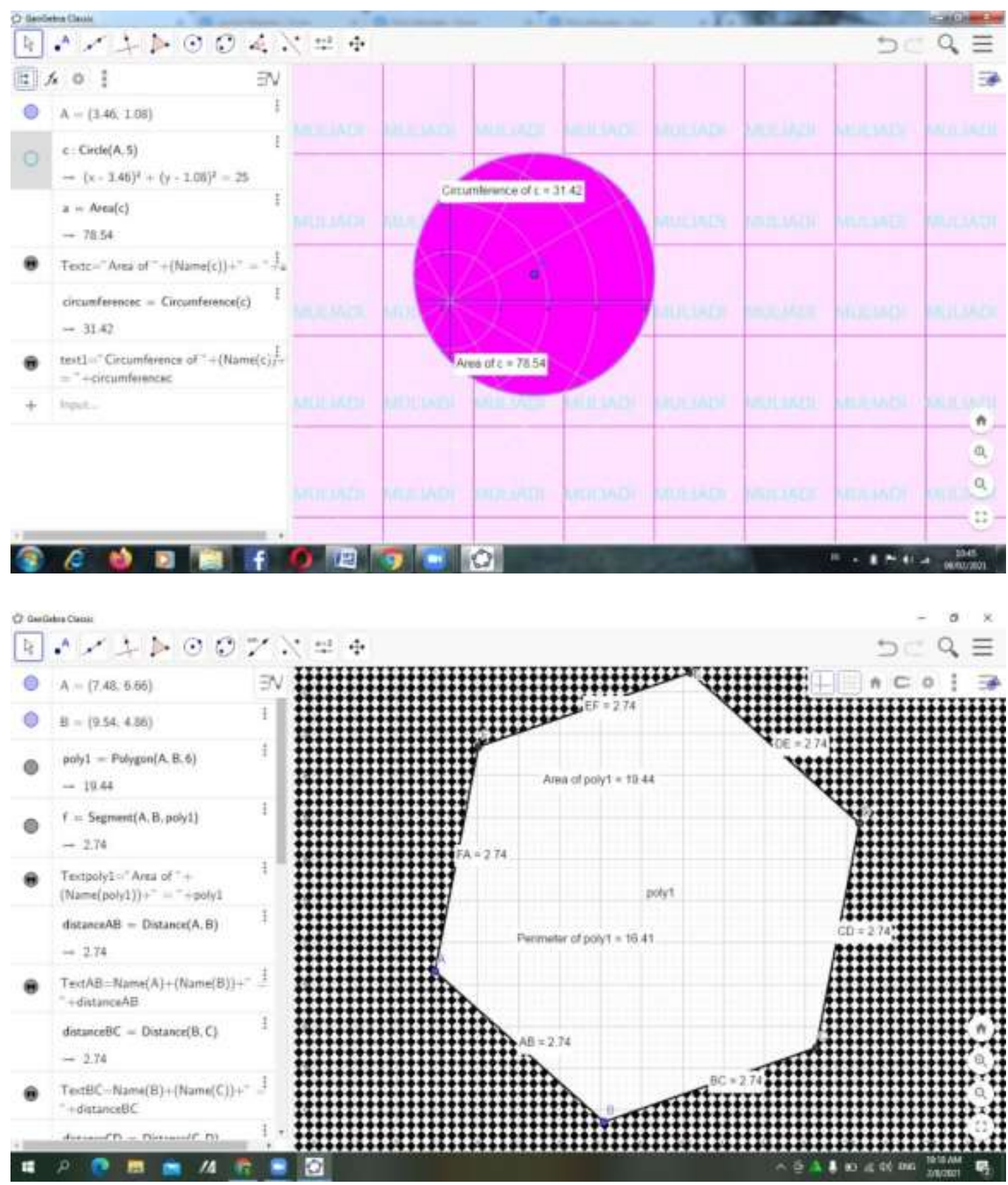
6395 Pengembangan Pembelajaran Matematika Berbasis Pendekatan Pembelajaran Mengalami Interaksi Komunikasi dan Refleksi (MIKIR) - Indra Maryanti, Nur 'Afifah, Ismail Saleh Nasution, Sri Wahyuni DOI : https://doi.org/10.31004/basicedu.v5i6.1814

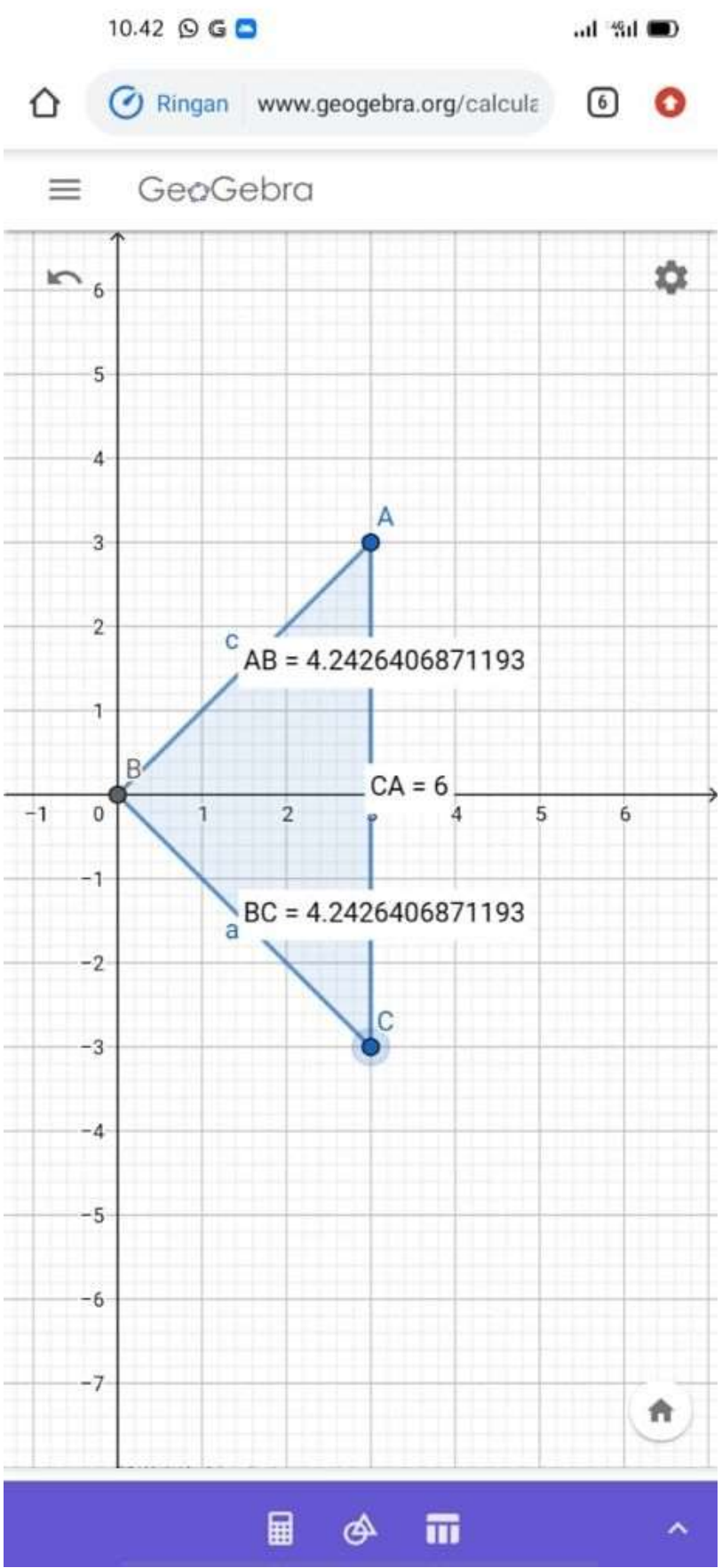

3) Komunikasi

Kemudian dosen mempersilahkan setiap kelompok untuk mejelaskan hasil diskusinya secara bergantian, dan mempersilahkan kelompok yang lainnya untuk menanggapi hasil diskusi dari kelompok yang presentasi.

4) Refleksi

Kemudian dosen mengarahkan mahasiswa dalam melakukan refleksi dengan pertanyaan sebagai berikut:

a. Bagaimana menemukan panjang sisi segitiga?

b. Bagaimana menemukan besar sudut sisi segitiga? 
6396 Pengembangan Pembelajaran Matematika Berbasis Pendekatan Pembelajaran Mengalami Interaksi Komunikasi dan Refleksi (MIKIR) - Indra Maryanti, Nur 'Afifah, Ismail Saleh Nasution, Sri Wahyuni DOI : https://doi.org/10.31004/basicedu.v5i6.1814

c. Bagaimana menemukan Keliling segitiga?

d. Bagaimana menemukan luas segitiga?

e. bagaimana Langkah-langkah dalam menemukan luas dan keliling segi- $\mathrm{n}$ beraturaturan?

f. Apa saja kesulitan yang ditemui dalam pembelajaran hari ini?

Kemudian hasil refleksi ini dikumpulkan melalui wa group. Dan dosen memberikan penguatan tentang pembelajaran yang telah dilakukan terutama dalam menentukan besar sudut, panjang sisi, keliling dan luas segitiga dan segi-n.

Dari hasil pengamatan peneliti tentang proses pembelajaran yang sudah dilakukan oleh dosen pengampu dapat disimpulkan bahwa dosen pengampu mata kuliah sudah memahami mengenai penggunaan LK sebagai alat bantu dalam proses pembelajaran dengan pendekatan mikir dan LK tersebut sudah sangat sesuai dengan skenario yang dibuat oleh dosen pengampu. Dosen pengampu sudah benar dalam proses pelaksanaan pembelajaran dengan pendekatan mikir yang dicetuskan oleh Tanoto Foundation. Keberhasilan guru dalam proses pembelajaran bisa dilihat dari perubahan positif pada diri siswa, Belajar akan bermakna apabila siswa mampu mengalami sendiri pada dirinya dan terjadi perubahan yang mengarah kepada kebaikan. Dalam penerapan unsur belajar aktif mengalami dengan jalan pengamati, melakukan percobaan, berwawancara dan membauat karya yang harus dilakukan oleh siswa. maka guru bisa memunculkan tindakan dan merespon apa yang dilakukan oleh siswa. Adapun tindakan dan respon guru adalah sebagai berikut: 1) memperhatikan dengan sekasa apakah pengamatan yang dilakukan oleh siswa itu benar benar sudah dilakukan secara teliti,cermat dan memastikan siswa mencatat hasil pengamatan secara lengkap dan benar; 2) Mengajukan pertanyaan pancingan agar siswa mendapat informasi lebih banyak sehingga kemampuan siswa untuk memahami dan menguasai materi menjadi kaya; 3) Sesekali mengajukan pertanyaan/memberikan komentar terhadap jawaban yang diberikan oleh siswa; 4) Mengamati terutama kalau ada langkah kerja yang membahayakan; 5) Mempertanyakan langkah tertentu terutama dari segi efektivitasnya; dan 6) Memberikan pendampingan bagi siswa yang mengalami keterlambatan atau kekurang sempurnaan dalam melakukan kegiatan percobaan (Foundation, 2018).

Setelah data diketahui sebagaimana penulis sajikan pada fakta temuan diatas, maka tindak lanjut dari penelitian ini yaitu analisis data yang terkumpul menggunakan metode penelitian kualitatif deskriptif secara terperinci.

Adapun pengembangan pendekatan pembelajaran mengalami, interaksi, komunikasi, dan refleksi (mikir) adalah sebagai berikut :

1. Perencanaan Pembelajaran dengan menggunakan Pendekatan Mikir

Perencanaan pembelajaran merupakan suatu keputusan yang ditetapkan untuk dilakukan didalam sebuah pembelajaran agar tujuan yang telah ditentukan tercapai. Perencanaan pembelajaran memudahkan dosen dalam melaksanakan proses pembelajaran. Perencanaan pembelajaran mempunyai peran yang sangat penting dalam terjadinya suatu pembelajaran, dikarenakan disaat dosen menyusun suatu perencanaan pembelajaran, dosen telah mengetahui seperti apa pembelajaran tersebut akan berlangsung dan bagaimana langkah-langkah agar tujuan dari pembelajaran tersebut tercapai.

Perencanaan pembelajaran pada pendekatan pembelajaran mikir sama seperti perencanaan pembelajaran pada umumnya. Hanya saja dalam pendekatan pembelajaran mikir dosen harus kebih kreatif dan inovatif dalam menentukan dan mengkreasikan proses pembelajaran karena dosen bertindak sebagai fasilitator yang memandu jalannya suatu pembelajaran, dan yang berbeda dalam penyusunan perencanaan pembelajaran mikir dengan yang lain adalah pendekatan pembelajaran mikir menggunakan skenario pembelajaran sebagai langkah awal yang harus disusun oleh dosen sebelum melaksanakan kegatan belajar.

2. Pelaksanaan Pembelajaran dengan Pendekatan Mikir di jurusan pendidikan matematika UMSU

Pelaksanaan pembelajaran adalah suatu proses yang diatur sedemikian rupa menurut langkahlangkah yang disusun dalam rencana pembelajaran agar pelaksanaan mencapai hasil yang diharapkan. 
6397 Pengembangan Pembelajaran Matematika Berbasis Pendekatan Pembelajaran Mengalami Interaksi Komunikasi dan Refleksi (MIKIR) - Indra Maryanti, Nur 'Afifah, Ismail Saleh Nasution, Sri Wahyuni DOI : https://doi.org/10.31004/basicedu.v5i6.1814

Pelaksanaan pembelajaran bernilai edukatif yang terjadi antara dosen dan mahasiswa, dikarenakan pelaksanaan pembelajaran diarahkan pada tujuan yang harus dicapai dalam suatu pembelajaran. dalam pelaksanaan pembelajaran pada umumnya dosen menyusun SAP sebagai pedoman dalam melaksanakan suatu pembelajaran, hanya saja dalam pembelajaran menggunakan pendekatan mikir dosen membuat SAP secara singkat yang disebut dengan skenario pembelajaran.

Didalam pelaksanaan pembelajaran menggunakan pendekatan pembelajaran mikir sangat berbeda dengan proses pembelajaran pada umumnya dikarenakan dengan menggunakan pendekatan mikir dosen hanya bertindak sebagai fasilitator atau sebagai pemandu suatu pembelajaran yang pada intinya proses pembelajaran bergantung pada keaktifan mahasiswa. Dalam proses pelaksanaan pembelajaran menggunakan pendekatan pembelajaran mikir ada beberapa komponen yang harus ada didalam proses pembelajaran yaitu "Mengalami" dalam belajar melibatkan banyak indera sehingga pemahaman konsep akan lebih mantap, "Interaksi" dapat mendorong mahasiswa untuk ungkap gagasan dan merefleksi diri sehingga menunjang pula pemahaman konsep secara baik, "Komunikasi" dapat memotivasi mahasiswa untuk berani dan lancar dalam menyampaikan gagasan, dan "Refleksi" memunculkan sikap untuk mau menerima kritik dan memperbaiki diri, baik gagasan, hasil karya maupun sikapnya.

3. Evaluasi Pembelajaran dengan pendekatan mikir di jurusan pendidikan matematika UMSU

Di dalam dunia pendidikan penilaian adalah bagian yang sangat penting karena itu menjadi bahan evaluasi selama proses pembelajaran. dalam penilaian memiliki tiga pencapaian yang harus dinilai oleh seorang dosen yaitu: kognitif, afektif, dan psikomotor. Penilaian kognitif yaitu penilaian yang mengukur kemampuan atau pengetahuan yang dimiliki peserta didik. Afektif yaitu penilaian yang mengukur dari sikap mahasiswa, dan penilaian psikomotor yaitu penilaian yang mengukur ketrampilan yang dimiliki oleh mahasiswa. Ketiga hal tersebut harus menjadi focus penilaian bagi seorang dosen.

Evaluasi yang dilaksanakan dalam proses pembelajaran dengan menggunakan pendekatan pembelajaran mikir menggunakan teknik rekapitulasi yang dilakukan mahasiswa selama dikelas maupun diluar kelas. Proses evaluasi pada pendidikan nilai dilakukan berdasarkan hasil yang diraih mahasiswa selama mengikuti pembelajaran. Evaluasi atau peniilaian dalam pendekatan pembelajaran mikir dilakukan dengan berbagai macam penilaian salah satunya dengan menggunakan LK (Lembar Kerja), lembar kerja pada umumnya hanya membahas mengenai pengetahuan yang diperoleh mahasiswa selama pembelajaran dan dirumuskan dalam bentuk tulisan namun dalam penilaian menggunakan pendekatan mikir, lembar kerja berisi hal yang didapatkan mahasiswa selama proses pembelajaran dan dikreasikan dalam bentuk gambar atau lainyaa. Jadi anak akan semakin kreatif dan inovaif dalam memeparkan hasil dari suatu pembelaaran. Dosen dapat melakukan penilaian melalui kretifitas, keaktifan saat pembelajaran, kinerja saat melakukan diskusi, dan lain sebagainya.

Dengan adanya penelitian ini penulis mengetahui bahwa bentuk evaluasi atau penilaian yang dilakukan kepada mahasiswa dapat dilakukan dengan beranekaragam bentuk, tidak melulu hanya melakukan penilaian secara pengetahuan tapi juga melakukan penilaian ketrampilan, keaktifan, dan kreatifitas sesuai dengan bagaimana yang dosen persiapkan dan materi yang dipelajari.

4. Peran dosen dalam pengimplementasian pendekatan pembelajaran mikir

Sehubungan dengan fungsinya sebagai pengajar, pendidik dan pembimbing, maka diperlukan adanya berbagai peranan pada diri dosen, peranan dosen ini akan senantiasa menggambarkan pola tingkah laku yang diharapkan dalam berbagai interaksinya, baik dengan peserta didik, dosen dan lainya. Peran dosen dalam proses pembelajaran adalah adanya tanggungjawab terutama dalam pengembangan potensi manusia (peserta didik). Dosen adalah ujung tombak pendidikan dikarenakan seorang dosen secara langsung berupaya memperngaruhi, dan mengembangkan kemampuan mahasiswa menjadi manusia yang cerdas dan terampil. Dalam proses pembelajaran dosen mempunyai peran yang sangat dominan dalam 
6398 Pengembangan Pembelajaran Matematika Berbasis Pendekatan Pembelajaran Mengalami Interaksi Komunikasi dan Refleksi (MIKIR) - Indra Maryanti, Nur 'Afifah, Ismail Saleh Nasution, Sri Wahyuni DOI : https://doi.org/10.31004/basicedu.v5i6.1814

pendidikan pada umunya. Karena dosen memegang peranan dalam proses pembelajaran, dimana proses pembelajaran merupakan inti dari proses pendidikan secara keseluruhan.

Peran dosen dalam pengimplementasian pendekatan pembelajaran mikir dengan peran dosen dalam pengimplementasian pendekatan pembelajaran lainya sama yaitu mempunyai peran yang sangat penting dikarenakan dalam pendekatan pembelajaran mikir dosen berperan secara langsung dalam proses pembelajaran sebagai fasilitator, agar pembelajaran dikatakan berhasil dosen berperan sangat penting dalam menentukan metode, model, media, dan strategi dalam pembelajaran. Dosen berperan penting dengan mempersiapkan secara matang pembelajaran yang akan diajarkan sehingga dalam proses pembelajaran dapat berjalan secara efektif dan tidak kekurangan waktu sehingga semua materi tersampaikan. Selain itu dosen juga berperan sebagai pengatur kelas serta menjalankan pembelajaran menggunakan pendekatan pembelajaran mikir.

5. Peran kampus dalam pengimplementasian pendekatan pembelajaran mikir

Peran kampus dalam keberhasilan proses belajar merupakan tingkatan kedua selain peran dosen.

Peran kampus sangat penting dalam keberadaan sarana dan prasarana di kampus dalam upaya mendukung terlaksananya pembelajaran menjadi bagian yang sangat penting. Pemanfaatan sarana dan fasilitas kampus sebagai penunjang proses pembelajaran, pembelajaran akan berhasil dan optimal jika dosen mampu menyesuaikan sarana dan fasilitas kampus dengan materi yang akan disampaikan sehingga dapat memotivasi belajar siswa. Selain itu adanya sarana dan fasilitas di kampus menjadi sarana tersendiri bagi siswa untuk mengikuti pembelajaran serta mempelajari materi pembelajaran

Peran kampus dalam menerapkan pendekatan pembelajaran mikir tentunya sangat penting dikarenakan dalam proses pembelajaran menggunakan pendekatan pembelajaran mikir dosen membutuhkan fasilitas pendukung dalam menerapkan proses pembelajaran yang tentunya disediakan oleh kampus. Selain berperan sebagai penyedia fasilitas kampus juga berperan atas adanya penerapan pendekatan pembelajaran baru.

\section{KESIMPULAN}

Berdasarkan hasil penelitian dan pembahasan pada bab sebelumnya, dapat ditarik kesimpulan bahwa dosen pengampu sudah memahami tentang pendekatan pembelajaran mikir, dengan dibuktikan dari hasil observasi mengenai implementasi pendekatan pembelajaran mikir yang ada di jurusan pendidikan matematika UMSU yang sudah mengikuti prosedur yang ditetapkan. Selain itu, penulis menyimpulkan beberapa hal mengenai implementasi pendekatan pembelajaran mikir di jurusan pendidikan matematika UMSU, yaitu:

Secara keseluruhan dosen di jurusan pendidikan matematika UMSU dalam menyusun Satuan Pengajaran (SAP) atau Skenario Pembelajaran sudah memasukkan beberapa unsur yang ada dalam pendekatan pembelajaran mikir. Model, media, dan strategi yang digunakan dalam melaksanakan pembelajaran pun sudah sesuai, dan dalam pemilihannya juga disesuaikan dengan keadaan mahasiswa dan tema/materi. Pembelajaran dengan menggunakan pendekatan mikir sudah berjalan pada jurusan pendidikan matematika UMSU. Dalam setiap pembelajaran dengan menggunakan pendekatan ini, mahasiswa selalu merasa bersemangat dan senang, awal mula pendekatan mikir ini diterapkan di jurusan pendidikan matematika UMSU mahasiswa masih merasa malu-malu dalam bertanya atau dalam mengungkapkan pendapatnya, namun seringnya pembelajaran mikir ini diterapkan di jurusan pendidikan matematika UMSU mahasiswa menjadi ketagihan dan lupa waktu saat pembelajaran berlangsung karena mereka tidak merasakan kejenuhan. Adanya pendekatan pembelajaran mikir dengan menyisipkan literasi disela-sela sebelum dan sesudah pembelajaran membuat mahasiswa di jurusan pendidikan matematika UMSU menjadi gemar dan mempunyai kebiasaan membaca, dan adanya sudut baca di kampus, membuat mahasiswa semakin mudah dalam membiasakan literasi. Peran dosen dalam kegiatan pembelajaran ini sangat pentinng karena kreatifitas 
6399 Pengembangan Pembelajaran Matematika Berbasis Pendekatan Pembelajaran Mengalami Interaksi Komunikasi dan Refleksi (MIKIR) - Indra Maryanti, Nur 'Afifah, Ismail Saleh Nasution, Sri Wahyuni DOI : https://doi.org/10.31004/basicedu.v5i6.1814

dosen menjadi penentu dalam proses pembelajaran menggunakan pendekatan mikir ini, dikarenakan dosen bertindak sebagai fasilitator, dan siswa akan menjadi tokoh atau peran utama dalam setiap pembelajaran, dosen hanya perlu mengarahkan siswa dalam proses pembelajaran berlangsung dan siswa akan menunjukkan kretifitasnya masing-masing.

\section{DAFTAR PUSTAKA}

Ahern, S. F., Morley, P. T., \& Mccoll, G. J. (2016). Governing The Reform Of The Medical Internship. The Medical Journal Of Australia, 204(10), 374-375. Https://Doi.Org/10.5694/Mja15.01326

Ahmadi. (2011). Mengembangkan Pembelajaran Aktif, Inovatif, Kreatif, Efektif, Menyenangkan, Gembira Dan Berbobot. Prestasi Pustakaraya.

Asikin, M. (2011). Dasar-Dasar Proses Pembelajaran Matematika. Universitas Negeri Semarang.

Depdikbud. (2013). Modul Pengembangan Analisis Hasil Belajar Peserta Didik. Depdikbud.

Foundation, T. (2018). Modul I Praktik Yang Baik. In Modul I Praktik Yang Baik.

Ghony, D., \& Almansur, F. (2017). Metodologi Penelitian Kualitatif. Ar-Ruzz Media.

Gunawan, R. G., \& Putra, A. (2019). Pengaruh Strategi Belajar Aktif Sortir Kartu Terhadap Kemampuan Pemecahan Masalah Matematis. Jurnal Cendekia: Jurnal Pendidikan Matematika, 3(2), 362-370. Https://Doi.Org/10.31004/Cendekia.V3i2.119

Hasratuddin. (2018). Mengapa Harus Belajar Matematika. Perc. Edira.

Khairani, M., \& Febrinal, D. (2016). Pengembangan Media Pembelajaran Dalam Bentuk Macromedia Flash Materi Tabung Untuk Smp Kelas Ix. Jurnal Iptek Terapan, 10(2), 95-102. Https://Doi.Org/10.22216/Jit.2016.V10i2.422

Kurniawan, A. R., Kardi, S., \& Jandrakirana. (2016). Pengembangan Perangkat Pembelajaran Ipa Berbasis Pendekatan Penemuan Terbimbing Untuk Melatihkan Keterampilan Proses Siswa Sekolah Dasar. Jurnal Review Pendidikan Dasar: Jurnal Kajian Pendidikan Dan Hasil Penelitian, 2(2), 175-183.

Marhamah, M., Zulkardi, Z., \& Aisyah, N. (2014). Pengembangan Materi Ajar Pecahan Dengan Pendekatan Pmri Di Sd Negeri 21 Palembang. Jurnal Pendidikan Matematika, 5(2), 171-184. Https://Doi.Org/10.22342/Jpm.5.2.584.

Maskar, S., \& Anderha, R. R. (2019). Pembelajaran Transformasi Geometri Dengan Pendekatan Motif Kain Tapis Lampung. Mathema Journal Pendidikan Matematika, 1(1), 40-47.

Maskar, S., Dewi, P. S., \& Puspaningtyas, N. D. (2020). Online Learning \& Blended Learning: Perbandingan Hasil Belajar Metode Daring Penuh Dan Terpadu. Prisma, 9(2), 154 Https://Doi.Org/10.35194/Jp.V9i2.1070

Mustakim, M. (2020). Efektivitas Pembelajaran Daring Menggunakan Media Online Selama Pandemi Covid19 Pada Mata Pelajaran Matematika. Al Asma: Journal Of Islamic Education, 2(1), 1. Https://Doi.Org/10.24252/Asma.V2i1.13646

Pernantah, P. S. (2019). Desain Skenario Pembelajaran Aktif Dengan Metode "Mikir" Pada Mata Kuliah Pendidikan Ips. Indonesian Journal Of Social Science Education (Ijsse), 1(2), 146-155. Http://Ejournal.Iainbengkulu.Ac.Id/Index.Php/Ijsse

Raehang. (2014). Pembelajaran Aktif Sebagai Induk Pembelajaran Kooperatif. Jurnal Al-Ta'dib, 7(1), 149167. Ejournal.Iainkendari.Ac.Id/Al-Tadib/Article/View/249/239

Siregar, E. (2019). Tanoto Foundation Beri Pelatihan Belajar Aktif Untuk Para Dosen Di Sumut. Antara Sumut. Https://Sumut.Antaranews.Com/Berita/193718/Tanoto-Foundation-Beri-Pelatihan-Belajar-AktifUntuk-Para-Dosen-Di-Sumut 
6400 Pengembangan Pembelajaran Matematika Berbasis Pendekatan Pembelajaran Mengalami Interaksi Komunikasi dan Refleksi (MIKIR) - Indra Maryanti, Nur 'Afifah, Ismail Saleh Nasution, Sri Wahyuni DOI : https://doi.org/10.31004/basicedu.v5i6.1814

Sugiyono. (2016). Metode Penelitian Kuantitatif, Kualitatif Dan R\&D. Alfabeta.

Utami, Y. P., \& Dewi, P. S. (2020). Model Pembelajaran Interaktif Spldv Dengan Aplikasi Rumah Belajar. Mathema: Jurnal Pendidikan Matematika, 2(1), 24. Https://Doi.Org/10.33365/Jm.V2i1.572

Yantoro. (2020). Analysis Of Teacher's Ability In Applying Mikir Elements In Active Learning At High Classes In The Primary School. Jurnal Pajar ( Pendidikan Dan Pengajaran ), 4, 356-366. 